\title{
FACTORS CONTRIBUTING TO THE DECISION BY PREGNANT WOMEN TO BE TESTED FOR HIV
}

\section{Karin Minnie}

PhD, MCur - Obstetric and Neonatal Nursing Science, RN, RM, RCN, RNA, RNE, RAdvMid Senior Lecturer, School of Nursing Science, North-West University (Potchefstroom campus)

Corresponding author: Karin.Minnie@nwu.ac.za

\section{Hester Klopper}

PhD, MBA, RN, RM, RCN, RPN, RNA, RNE

Professor, School of Nursing Science, North-West University (Potchefstroom campus)

\section{Christa van der Walt}

PhD, MCur, MEd, RN, RM, RCN, RNA, RNE

Associate Professor, School of Nursing Science, North-West University (Potchefstroom campus)

Keywords: decision-making; pregnant women; HIV; prevention of mother-to-child transmission; counselling for HIV testing

\begin{abstract}
The objective of this study was to explore and describe the factors that influence the decision by pregnant women to be tested for HIV. This was achieved through a qualitative research study that was exploratory, descriptive and contextual in nature. A sample of 13 pregnant women participated. Data obtained from semi-structured interviews was analysed according to a protocol based on a combination of methods of analysis. The three main themes, namely factors that contribute to the decision by pregnant women to be tested for HIV, factors that contribute to the decision by pregnant women not to be tested for HIV and organisational factors that influence the decision by pregnant women to be tested for HIV, were divided into nine subthemes. Conclusions and recommendations to promote counselling to pregnant women being tested for HIV are provided.
\end{abstract}

\section{OPSOMMING}

Die doel van die studie was om die faktore wat die besluit van swanger vroue om vir MIV getoets te word, te verken en beskryf. Dit is gedoen deur middel van verkennende, beskrywende, kontekstuele kwalitatiewe navorsing. ' $n$ Steekproef van 13 swanger vroue het deelgeneem. Inligting is verkry deur middel van semi-gestruktureerde onderhoude. Hierdie inligting is ontleed aan die hand van 'n protokol gebaseer op 'n kombinasie van ontledingsmetodes. Die drie hooftemas, naamlik faktore wat bydra tot swanger vroue se bes/uit om vir MIV getoets te word, faktore wat bydra tot swanger vroue se besluit om nie vir MIV getoets te word nie en organisatoriese faktore wat swanger vroue se besluit beïnvloed om vir MIV getoets te word, is in nege subtemas onderverdeel. Gevolgtrekkings en aanbevelings ter bevordering van berading van swanger vroue vir MIV-toetsing, word verskaf. 


\section{INTRODUCTION}

HIVIAIDS is one of the most serious health crises the world has to deal with. In South Africa, current figures indicate that $29,1 \%$ of pregnant women are infected (National Department of Health, 2007:2). When pregnant women are infected, their own lives and the lives of their unborn babies are at risk. According to the World Health Organization, 700000 babies are infected annually (WHO, 2007).

The implementation of strategies based on research findings has made it possible to limit mother-to-child transmission to a large extent. The Nevirapine regime, as used up to 2008, reduces the risk of vertical transmission (during pregnancy and labour) from 23\% to $13 \%$ (McCoy, Besser, Visser \& Doherty, 2002:26). The risk of transmission during pregnancy is $7 \%$, and use of the regime reduces the risk during the birth process from $16 \%$ to $6 \%$ (McCoy et al., 2002:26). The new dual-therapy ( $A Z T$ and Nevirapine) that is being implemented in South Africa can reduce the risk of transmission during pregnancy and birth to below 5\% (McIntyre, 2005:975). The risk can be limited even further by adapting the method of feeding that the baby receives.

Initially, strategies merely focused on the prevention of mother-to-child transmission. This research focus is increasingly shifting towards strategies that would support the HIV-positive pregnant woman (UNICEF/ UNAIDS/WHO/UNFPA, 2000:5). Lifestyle adjustments and a healthy diet can enable people living with HIV to stay healthy for longer. Women who can afford it and those who qualify for the subsidised treatment of the South African Department of Health can benefit from anti-retroviral therapy, which aims to promote the HIVpositive person's health and not just prevent transmission to the baby. Women and their babies can only benefit from these strategies if their HIV-positive status is known.

However, according to the District Health Barometer of $2006 / 2007$, only $75 \%$ of the pregnant women who used the public health services in South Africa were tested for HIV in 2006 (Barron, Day \& Monticelli, 2007:69). In 2003, in a study done in the same subdistrict as the present study, only $59,1 \%$ of the women indicated that they had been tested for HIV during pregnancy (Minnie
\& Greeff, 2006:24). Considering that an estimated $29,1 \%$ of pregnant women in South Africa are HIV positive (National Department of Health, 2007:2), a large number of women and their babies do not benefit from the strategies available for preventing mother-to-child transmission and promoting the health of HIV-positive women. The question arises why pregnant women decide not to be tested for HIV when counselling is available and when knowing their status holds obvious benefits for themselves and their babies.

\section{PROBLEM STATEMENT}

Although it may seem evident that it is beneficial to a woman and her baby if she is aware of her HIV status, she does not necessarily experience it as such. Some of the reasons that were raised by women in the USA were fear of a positive result, potential violent reactions from their partners, and fear of stigmatisation and discrimination (Aynalem, Mendoza, Frederick \& Mascola, 2004:29; Parra, Doran, Ivy, Aranda \& Hernandez, 2001:89). Some women also display a lack of knowledge regarding the implications of testing positive (Sanne \& Smego, 1998:39). Parra et al. (2001:92) add that some women experience denial about a possible infected status and a fatalistic attitude. In Kenya, $15 \%$ of the women did not consider knowing their status to be beneficial as it might lead to depression, since AIDS is incurable (Gaillard, Meilis, Mwanyumba, Claeys, Muigai, Mandaliya, Bwayo \& Temmerman, 2000:334). When she decides whether or not to be tested for HIV, the pregnant woman's personal considerations play an important role in the question as to why the status of so many women is not known.

During counselling, the factors influencing pregnant women in their choice to be tested for HIV need to be taken into consideration to facilitate the willingness of pregnant women to be tested. If the uptake of HIV testing improves, more women and their babies could benefit from prevention of mother-to-child transmission and HIV treatment strategies.

\section{OBJECTIVE OF THE STUDY}

The objective of this study was to explore and describe the factors that influence the decision by pregnant women to be tested for HIV in antenatal clinics in the 
North West. This information was used as part of research evidence on which best practice guidelines (BPGs) for counselling for HIV testing during pregnancy were based.

\section{CLARIFICATION OF KEY CONCEPTS}

\section{Model of HIV testing}

In the context of this research a combination of clientinitiated voluntary counselling and testing (VCT) and routine offer of HIV testing by the health care provider is practised (Minnie, 2007:11).

\section{Counselling for HIV testing}

For the purpose of this research, counselling is the process of assisting the pregnant woman in making a decision to be tested for HIV or not. Counselling for HIV testing involves transmission of information as well as provision of support (Minnie, 2007:11).

\section{RESEARCH DESIGN}

The objective was achieved through a qualitative research study that was exploratory, descriptive and contextual in nature. According to Polit and Beck (2004:20), the goals of exploratory research are to understand the underpinnings of specific phenomena and to explain systematic relationships amongst phenomena. The study can also be considered descriptive as the phenomenon is described in rich detail. It addresses the question "What is going on?", grounded in the data from which it was derived (Burns \& Grove, 2005:57), and is contextual in nature since validity of the findings is claimed only in the specific context in which the study was conducted.

Insight into the 'lived world' of a pregnant woman having to decide if she wants to be tested for HIV could assist in understanding the dynamics that are at play. According to Kvale (1996:31), interviews are ideally suited when attempting to understand an issue from the participant's point of view. The knowledge of the insider's (emic) perspective in this study provided valuable evidence in the development of the BPGs.

\section{RESEARCH METHODS}

\section{Population and sampling}

The population consisted of women who attended the antenatal clinics in the southern district of the North West and who had received pretest counselling in the period September-October 2006.

The participants were purposively selected in a stepwise process when one of the two subdistricts in the district was randomly selected. Four of the seven clinics in the subdistrict were then randomly selected, after which one day for each clinic was randomly selected for data collection on the understanding that additional days would be scheduled if data saturation was not reached after the analysis of the initial interviews. On the selected day, all pregnant women were asked if they would be willing to be interviewed and were included if they consented. Data saturation was used as a criterion for sample size (Greeff, 2005:294) and 13 pregnant women were sampled and interviewed $(n=13)$ before data was saturated.

Whether the woman agreed to be tested for HIV or not was not used as an inclusion criterion owing to the high level of stigmatisation in the community. If only those who agreed or who did not agree to be tested had been selected, women might have been afraid to participate as they might have felt that their participation might have indicated their HIV status.

\section{Data collection}

Data was collected by means of semi-structured individual interviews. As both open-ended and closed questions were used, this type of interview can be classified as semi-structured, according to Gillham's scale (2000:6). Closed questions were used to gather factual data such as biographical information, but most questions were open ended, as this type of question is most suitable for exploring a topic or collecting in-depth information as suggested by Gillham (2000:3). One central question was asked, namely: In your opinion, what factors influence the decision of a pregnant woman to be tested for HIV?

Because of the sensitivity that surrounds HIV in the community and the risk of harm that might be caused 
by potential stigmatisation, the strategy to collect the relevant data by indirect questioning regarding the factors that influence the decision of a pregnant woman, and not asking about the factors that influenced her own decision, was used to minimise discomfort for the women and thus reduce the risk of harm.

After approval to continue with the research from the Ethics Committee of the North-West University had been granted (certificate number: 04K26), permission was obtained from the Department of Health of North West, and the subdistrict manager under whose authority the selected clinics fall was notified. The registered nurses in charge of the clinics were also notified and suitable dates for collecting data were agreed upon.

The interviews were conducted in private rooms at the different clinics during the women's routine antenatal visits. Precautions such as a 'Do not disturb' notice on the door were taken to ensure privacy and limit interruptions. Despite these precautions some of the interviews were interrupted. However, the interruptions did not seem to influence the participants negatively. On the day of the interview, all the pregnant women in the waiting room of the specific clinic who had already received counselling for HIV testing were briefed about the research and invited to participate. Women who indicated that they would be willing to participate in the study were taken to the private room and informed consent was obtained before the interview commenced. Women were also informed that an interpreter was available if needed. A tape recorder and an electronic voice recorder were used to record the interviews after permission to do so was obtained from the participant.

In a research interview it is up to the interviewer to establish a rapport that allows interaction which, within a short time, leads beyond a merely polite conversation or exchange of ideas (Kvale, 1996:128). The interviewer therefore used communication techniques that are effective in establishing a rapport (Okun, 2002:33, 81; Greeff, 2005:289). The non-verbal communication skills used included appropriate and responsive facial expressions, occasional eye contact, as extensive eye contact can cause the interviewee to feel embarrassed or dominated, economic use of head nodding as encouragement, and natural gesturing (Gillham, 2000:30). The verbal dimension of active listening includes listening rather than talking and using an appropriate, natural-sounding tone of voice (Gillham, 2000:34). During the interviews with the pregnant women, the interviewer kept the objective of the study in mind and kept the interview focused.

As recommended by Kvale (1996:128), the interviews were rounded off by mentioning some of the main points learned from the interview. This served as debriefing of the tension or anxiety that can be experienced when personal and emotional experiences are shared. The 13 interviews lasted between 20 and 40 minutes each.

Kvale (1996:129) mentions the value of the interviewer's personal reflection after each interview. Directly after each interview, the interviewer recorded field notes on her observations and interpretation of what happened during the interview (Greeff, 2005:298). These immediate impressions provided valuable context for data analysis. Before data analysis, the field notes were combined with the transcribed interviews to provide insight into the situation during the interview. Anonymity was ensured by not using the participants' real names during the interviews as well as in the discussion. Participants' information was kept confidential by only referring to it as part of the combined research report.

\section{Data analysis}

As the study was qualitative in nature, data analysis was not a once-off occurrence, but a process that started with the knowledge and anticipated meaning that the researcher had gained through experience and contact with the literature (Creswell, 2003:190). Data analysis continued during data collection since the researcher (and co-analyst) reflected on the raw data as it became available and the interviews were transcribed (Richards, 2005:68). An eclectic approach was used during the data analysis process. The general principles of handling qualitative data as discussed by Richards (2005:67-82), and the steps of content analysis according to Gillham (2000:63-66) were combined with the data analysis process developed by Tesch in 1990 and summarised by Creswell (2003:192) to develop a protocol to serve as a guideline during the formal data analysis.

During the first two steps, the two analysts read through all the transcripts independently to obtain a general sense of the information, and then highlighted all the 
participants' statements that made a substantial point. As advised by Gillham (2000:63), the transcripts were read through repeatedly to ensure that all the substantive statements had been identified.

In step three all the substantive statements were listed, themes were clustered together and arranged in columns. Each theme was allocated a provisional code. In the fourth step the analysts went through all the transcripts and marked the statements with the codes allocated to the themes. As the process continued, the grouping of the themes was revised to include new ones and to combine those that related to one another when new insights emerged as the analysts became immersed in the data. At this stage the two analysts compared their work and discussed the differences and similarities in order to reach consensus.

In step five the most descriptive wording for each theme was identified and themes divided into main themes and subthemes. Again, the themes were reconsidered and changed where necessary. In step six a final list of themes was compiled, while the seventh step entailed the combining of all the data that belonged to each theme. The statements were marked with the interview number and the page number within the transcription. In vivo quotations that were considered strikingly representative of the theme or subtheme were selected for use in the discussion of the results. Data that was irrelevant to the research question and objective was discarded.

At this stage a second meeting with the co-analyst was held to discuss the final themes. A few minor adjustments were made. Once again, all the categorised themes and subthemes were revised, keeping the research objective in mind.

\section{LITERATURE CONTROL}

After consensus was reached on the major themes and subthemes, the literature was scrutinised to compare and contrast the findings. According to Creswell (2003:31), this approach is suitable for the inductive process of qualitative research, as the literature does not guide or direct the study, but becomes an aid once themes have been identified. Studies where researchers reached similar findings were identified. In cases where findings in the literature were not substantiated in this study, this study's unique findings were pointed out.

\section{RIGOUR}

Creswell (2003:195) regards validity as a strength of qualitative research. However, the term 'validity' is not used in the same context as in quantitative research, and is not associated with reliability or generalisability. He states that the term 'validity' as used in qualitative research is used to suggest the degree to which the findings are accurate from the viewpoint of the researcher, the participant, or the readers.

A combination of Guba's model for trustworthiness as discussed by Krefting (1991: 215), the threats to reliability and validity according to Woods and Catanzaro (1988:136-137), together with the strategies to control them as proposed by Creswell (2003:196), acted as a guideline to ensure rigour. The criteria according to Guba and the corresponding terms are discussed in Table 1, which indicates the relevance and application of strategies in this study.

\section{FINDINGS AND DISCUSSION}

A total of 13 interviews were conducted. With some of the interviews a relationship of trust was established quickly and rich data was obtained. A few of the participants clearly valued the opportunity to speak about their experience when expressing their appreciation, but others remained reserved and obtuse and the interviewer tried in vain to encourage them to contribute more. Mabunda (2006:23) also found in her study on knowledge and practices of voluntary HIV counselling and testing that some participants were reluctant to open up and discuss why they did not want to be tested.

The biographical information of the participants is presented in Table 2.

The themes and related subthemes are presented in Table 3. In the discussion, extracts from the original transcripts are inserted to provide evidence that supports themes and subthemes. Corresponding or conflicting findings found in the literature are cited in relation to the present findings. 


\begin{tabular}{|c|c|c|c|c|c|c|c|c|c|}
\hline 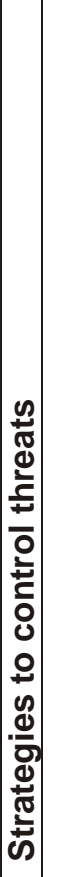 & \multicolumn{6}{|c|}{ 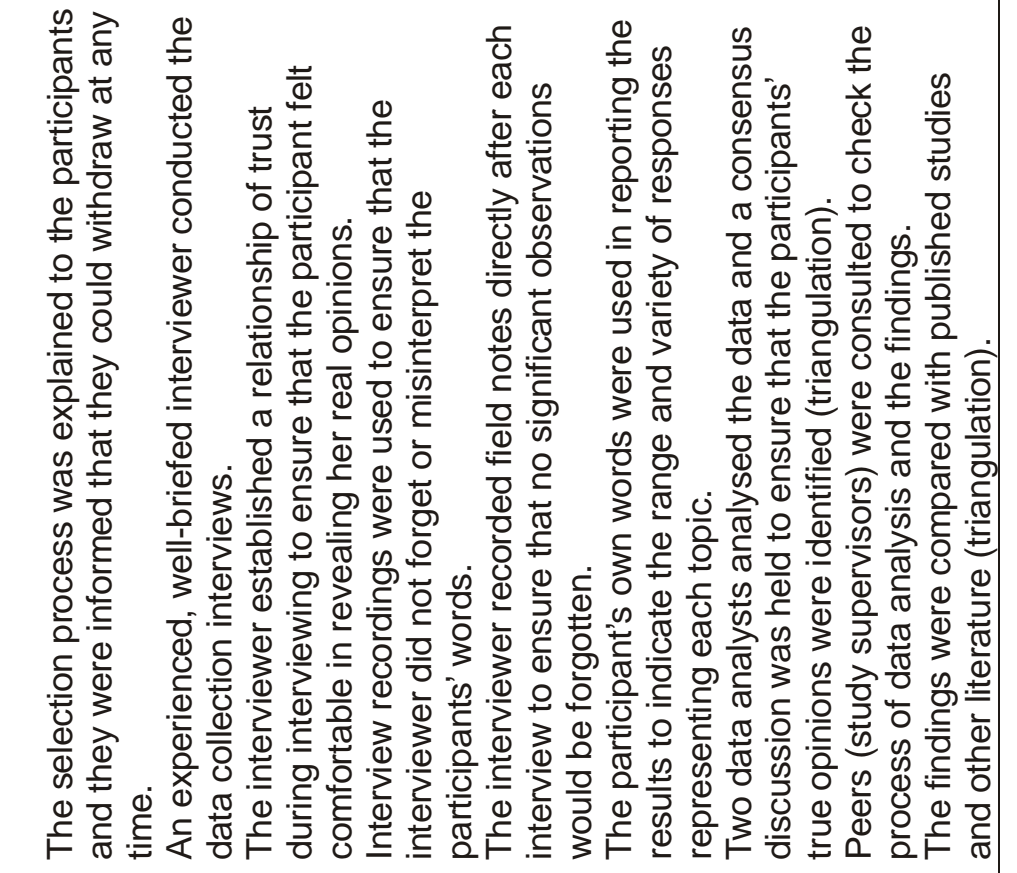 } & \multicolumn{3}{|c|}{ 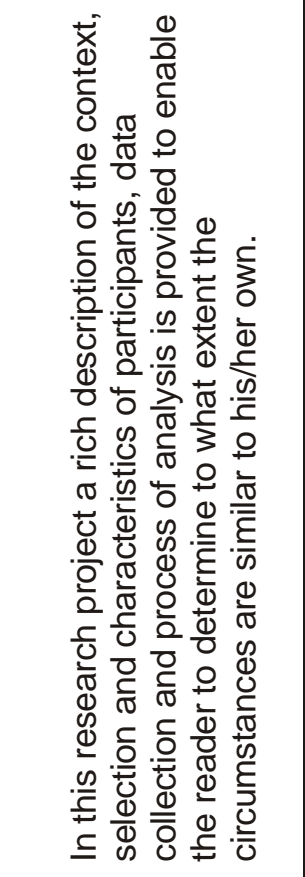 } \\
\hline 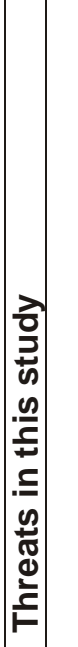 & 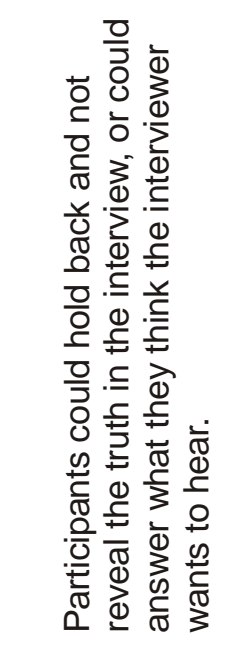 & 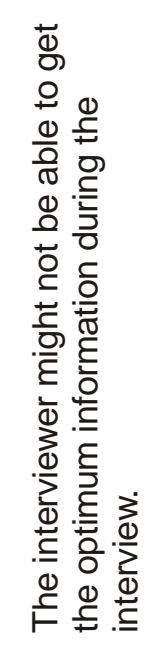 & 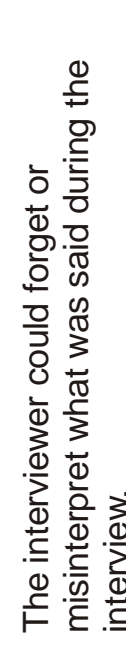 & 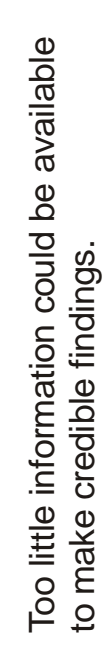 & 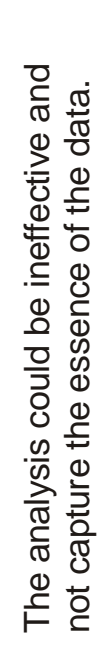 & 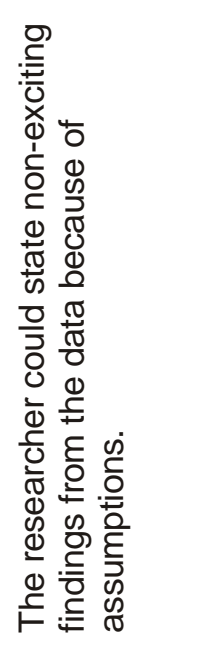 & & 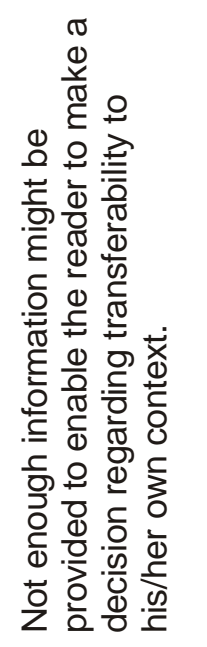 & 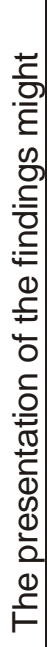 \\
\hline ن̀ & 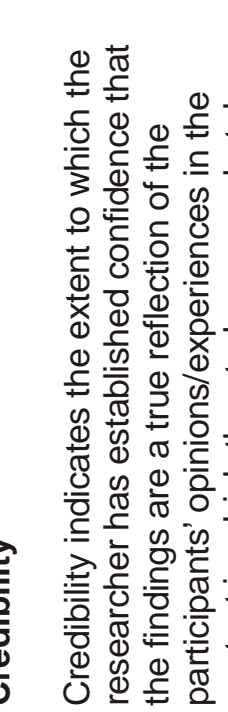 & 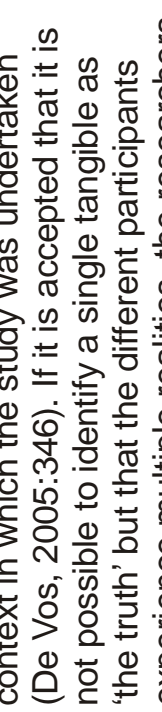 & 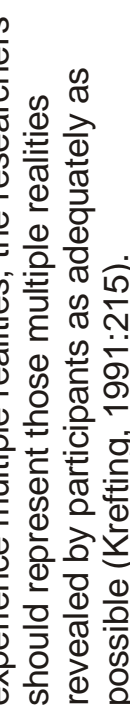 & & & & & 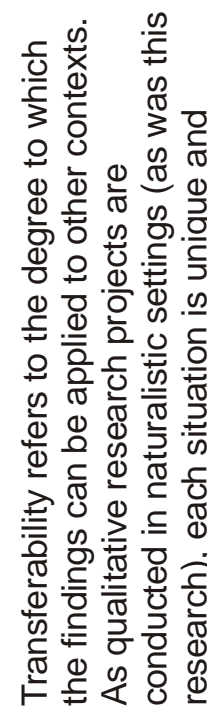 & \\
\hline
\end{tabular}




\begin{tabular}{|c|c|c|c|}
\hline 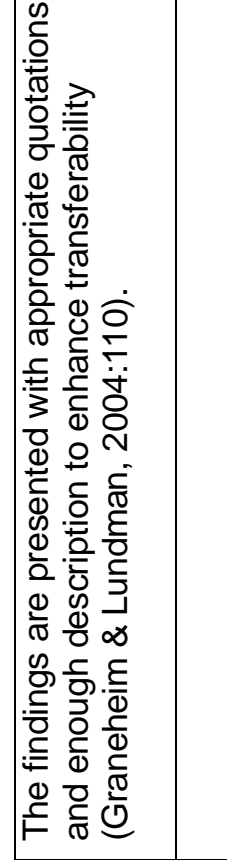 & 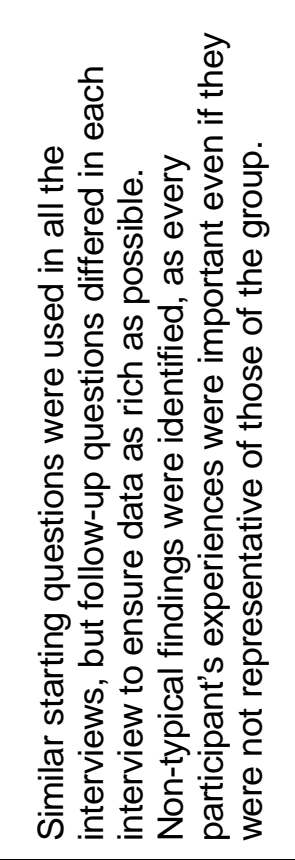 & 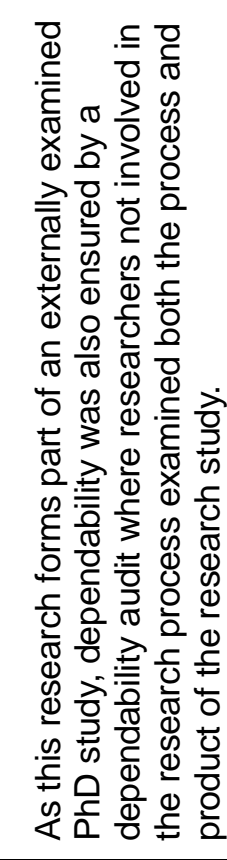 & 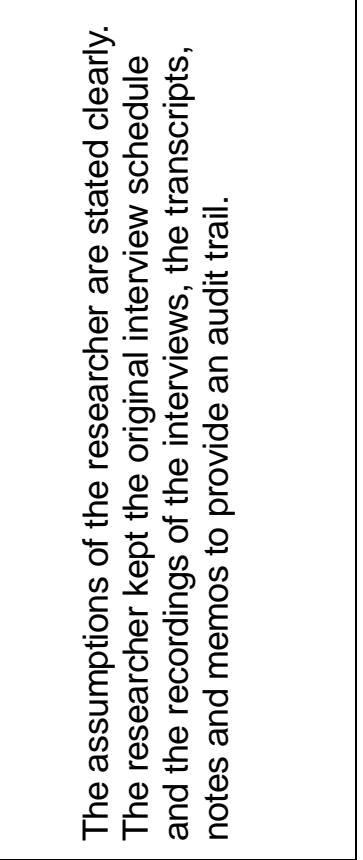 \\
\hline 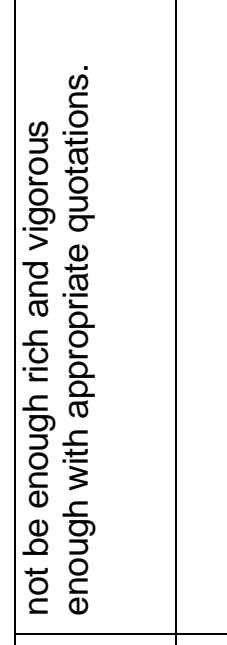 & 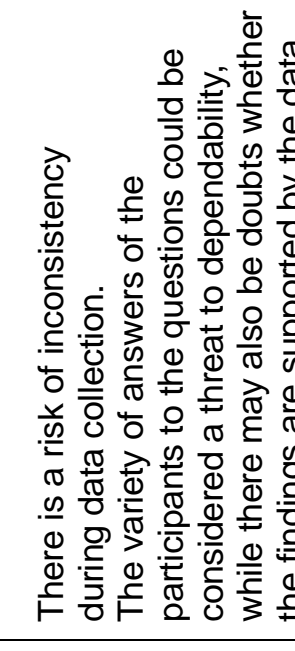 & & 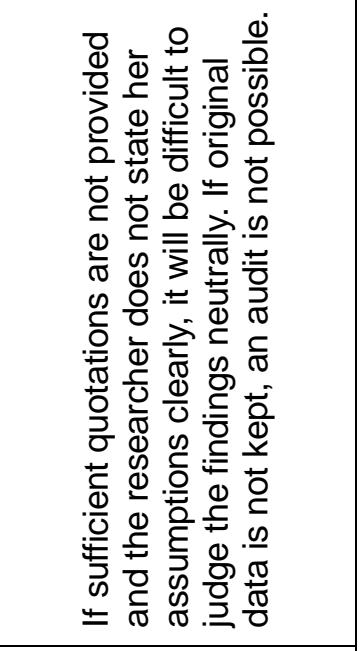 \\
\hline 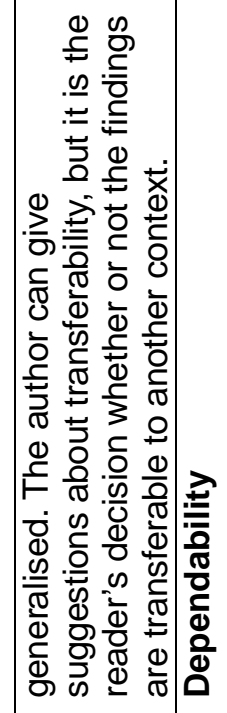 & 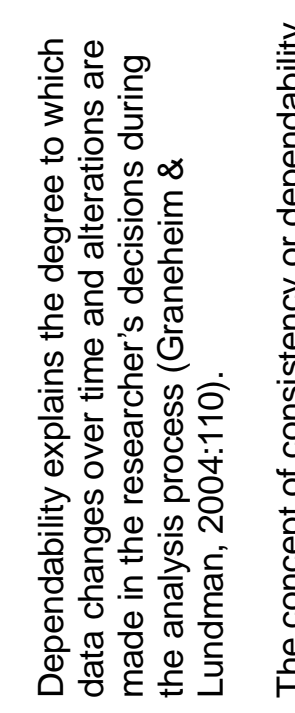 & 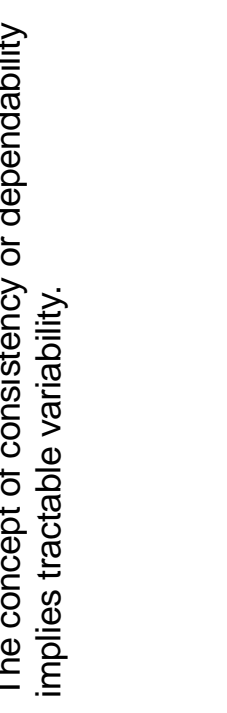 & 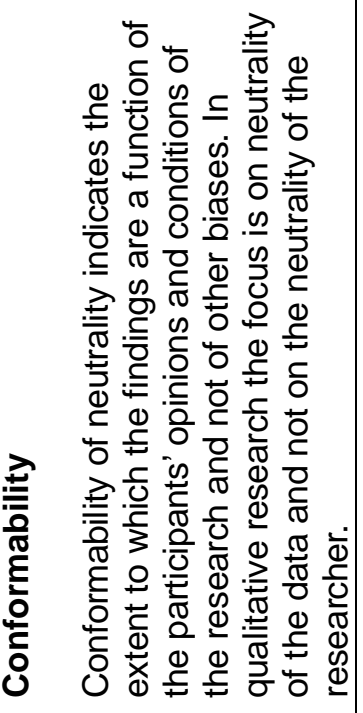 \\
\hline
\end{tabular}


Table 2: Biographical information of participants

\begin{tabular}{|l|l|}
\hline Age & $\begin{array}{l}\text { There was one teenager (19 years of age), eight participants were in } \\
\text { their 20s and four were older than 30. }\end{array}$ \\
\hline Gestational stage & $\begin{array}{l}\text { The participants' gestational ages ranged from 14 to } 40 \text { weeks, but } \\
\text { most participants were in their first or second trimester of pregnancy as } \\
\text { the participants were selected at the first antenatal visit, shortly after } \\
\text { they were counselled for HIV testing. }\end{array}$ \\
\hline Gravity & $\begin{array}{l}\text { There were two primigravidas, while nine were pregnant for the second } \\
\text { time and two participants were expecting their third child. }\end{array}$ \\
\hline Educational level & $\begin{array}{l}\text { Most of the participants had between 10 and 12 years of schooling, and } \\
\text { two were still scholars. }\end{array}$ \\
\hline Marital status & $\begin{array}{l}\text { Only one woman was legally married, but with the exception of one } \\
\text { participant all the others were in stable relationships with the father of } \\
\text { their baby. }\end{array}$ \\
\hline Place of residence & $\begin{array}{l}\text { Most lived with the father of the baby, while two stayed with their } \\
\text { parents and one with her grandmother. }\end{array}$ \\
\hline
\end{tabular}

Table 3: Main themes and subthemes identified during data analysis

\begin{tabular}{|c|l|}
\hline Themes & Subthemes \\
\hline 1 Factors that contribute to the decision by & 1.1 Own decision \\
pregnant women to be tested for HIV & 1.2 Influenced decision \\
& 1.3 Collective decision \\
\hline 2 Factors that contribute to the decision by & 2.1 Fear of personal changes if HIV positive \\
pregnant women not to be tested for HIV & 2.2 Fear of social changes if HIV positive \\
\hline 3 Organisational factors that influence the & 3.1 Format of counselling and testing \\
decision by pregnant women to be tested for & 3.2 Counselling as a source of support \\
HIV & 3.3 Counselling as a source of information \\
& 3.4 Logistical factors \\
\hline
\end{tabular}

\section{Factors that contribute to the decision by pregnant women to be tested for HIV}

Pregnant women, who had decided on their own to be tested for HIV, had various reasons for making this decision.

\section{Own decision}

A prominent reason why pregnant women decided to be tested, and mentioned by most of the participants, was that they wanted to know their HIV status for their baby's sake. This may indicate that the motivation was based on the women's knowledge about the measures that can be taken to prevent mother-to-child transmission of HIV, as well as a sense of responsibility concerning the baby's welfare. Some of the excerpts supporting this motivation are: "I think it's very good to test for the safety of the baby". "Ek gaan, ek moet vir die babatjie gaan, toe gaan ek". ("I must go, I must go for the baby, so I went"). Awareness of HIV status for the baby's sake was also found in a qualitative study by Boyd, Simpson, Hart, Johnstone and Goldberg (1999:25) regarding pregnant women's opinions of HIV testing in Scotland. It was also considered an important reason by the participants in the studies by Toivo (2005:34) as well as by Romero-Gutierrez, DelgadoMarcias, Mora-Escobar, Ponce-Ponce de Leon and Amador (2007:26).

One of the women indicated that although she thought 
it was necessary for pregnant women to know their status to protect their babies against possible motherto-child transmission of HIV, she did not see the benefit for herself: "If I was not pregnant, I was not going to do the test". This perception corresponds with the findings by Boyd et al. (1999:25), where no one spoke of the perceived benefits to themselves, but only to the baby. The focus on the benefits to the baby was logical in the era when anti-retroviral drugs were used only for PMTCT, but not since anti-retroviral therapy has been available to improve the health of all HIV-positive people.

In contrast to the opinion that there was no self-benefit for a woman in knowing her HIV status, some women consented to be tested mainly for their own sake. This motivation is evident from the following verbatim quotes from the interviews: " $E k$ voel dit is belangrik vir my, ek moet weet wat aangaan, want ek het nog 'n hele toekoms voor my". ("I feel it is important for me, I must know what's going on, because I have my entire future ahead of me.") "Ek wil weet waar ek staan". ("I want to know where I stand.") "It is important for me, not for someone else. For I, for myself". Studies by RomeroGutierrez et al. (2007:26) and Fernandez, Wilson, Ethier, Walter, Gay and Moore (2000:464) also found that the perceived benefits for the woman herself were important incentives to be tested.

Regardless of the motivation for testing, women can make the decision to be tested only once they are ready. This is an important consideration, as was stated by one of the participants: "I'll tell you if I am ready. You'll tell yourself, I am ready to test". A number of the women indicated that they were scared and took time to make the decision to be tested. They did not want to be pressured to decide, but wanted time to make a conscious decision. This train of thought is evident from the following quotes. "Were you scared yesterday, when you think of coming today?] Yeh, even this morning when I was coming, Joh!" "Ek het nie dieselfde tyd (direk na die berading) gegaan nie. Ek het eers gesit en dink, moet ek gaan of moet ek nie gaan nie? Op die laaste toe dink ek, nee, laat ek gaan vir die toets, want ek wil weet waar ek staan". ("I didn't go at the time of the counselling. I first sat and thought, must I go or mustn't I? Finally, I thought, no, let me go for the test, because I want to know where I stand.")
With regard to readiness, one participant mentioned that the counsellors had to give pregnant women more time to get ready to accept testing: "Sometimes they counsel us once, then I say no, I don't want to take the blood test. Then maybe if they come continuously, maybe some other day I will change my mind". Maman, Mbwambo, Hogan, Kilonzo and Sweat (2001:602) and De Paoli, Manongi and Klepp (2002:148) found that a one-time pretest counselling session may not be sufficient for pregnant women who visit an antenatal clinic not knowing that HIV testing will be offered.

\section{Influenced decision}

Although other studies have found that the decision to be tested for HIV is often made with input from other family members or a woman's partner (Cartoux, Msellati, Meda, Welffens-Ekra, Mandelbrot, Leroy, Van de Perre \& Dabis, 1998:2339; Beevor \& Catalan, 1993:3; Romero-Gutierrez et al., 2007:26), it was not found to be the case in this study. Only one of the participants was persuaded by a family member - her grandmother: "My ouma het gesê ek moet die toets maak". ("My grandmother told me to take the test.") This absence of input by significant others in the decision to be tested could be an indication that HIV testing is not discussed in the family, as it is considered a taboo subject owing to the associated stigma.

\section{Collective decision}

In a few cases the decision to be tested was made collectively when a group that had received health education about HIV together during the antenatal clinic session decided together: "When the first person says I want to test, then everyone say - I want to test".

Solomon, Van Rooyen, Griesel, Gray, Stein and Nott (2004:15) warn against the possibility that women who are part of a group that receives precounselling may feel pressured to 'consent' to testing. No evidence of women who felt coerced could be found in this study.

\section{Factors that contribute to the decision by pregnant women not to be tested for HIV}

The second main theme that crystallised relates to factors that contributed to the decision by pregnant women not to be tested for HIV. One of the main reasons given was that some of the participants were afraid of how a positive HIV diagnosis would change 
their lives in a negative way.

"Everything would change today if I was positive, everything!" "The world is going to be black - that is something!"

\section{Fear of personal changes if HIV positive}

The fear of the change in one's personal life could be enough of a deterrent to convince someone not to consent to be tested for HIV. Their living conditions as well as their health can be influenced negatively. The following excerpts indicate concern about the possible changes to the security of their living conditions or income: "... when you tell your partner or your parent ... sometimes you don't have a place to stay". "Hulle is bang .... dat hulle sal sukkel, hoe gaan hulle werk? .... Hoe gaan jy betaal vir alles?" ("They are afraid ... that they might struggle, how are they going to work? How are you going to pay for everything?"). This fear of losing security has also been noted in other studies (Pool, Nyanzi \& Whitworth, 2001:612; Cartoux, Sombié, Van de Perre, Meda, Tiendrébéogo \& Dabis, 1999:2343; Maman, 2003:4). Bodkin (2004:235) points to the sense of powerlessness and dependency many women face.

Some participants believed that pregnant women would prefer not knowing their status even though they may be infected, as they feared that they may get ill quickly after receiving the diagnosis, as indicated by the following quote: "....hulle sê miskien jy is positive, jy word siek vinnig want hulle het vir jou gesê". ("...they might say you are positive, you get ill quickly because they told you.") "The minute you get the results, and you're (positive), you are going to be stressed. You are going to be sick that moment".

Some participants in a study done by Toivo (2005:42) also believed that it was better for them not to be tested, as the knowledge of a positive status would bring death nearer. Some of the participants in the current study also shared this belief: "Hulle is bang hulle lewe gaan net daarop eindig". ("They are afraid their life will end right then.") "...as hulle sê jy is HIV positive, jy het niks tyd nou". ("If they say you are HIV positive, you have no more time.") This belief regarding death that follows soon after receiving a positive HIV diagnosis is supported in the literature (Van Dyk \& Van Dyk, 2003:120; Cartoux et al., 1998:2343).
The participants linked the idea of death following rapidly after a positive HIV diagnosis to both death from AIDS and death through suicide on receiving the news. This may indicate despair and experiencing no hope for the future: "Hulle dink net aan die dood". ("They just think about death.") "Party mense kan mos nie sulke goed hanteer nie. Ek meen daar is baie wat hulself dalk sal doodmaak". ("Some people cannot handle such things. I believe there are many who may kill themselves.")

According to Toivo (2005:44), people in Namibia often regard suicide as a solution to problems caused by finding out their HIV-positive status. Soon and Barnard (2002:16), as well as Marcenko and Samost (1999:39), also indicate the possibility that the despair experienced by HIV-positive people could lead to suicide.

\section{Fear of social changes if HIV positive}

Some participants believed that some pregnant women preferred not to know their HIV status, because they were afraid of the possible effect it would have on their relationship with their parents or partners. According to Marcenko and Samost (1999:39), Soon and Barnard (2002:16), as well as Yoshioka and Schustack (2001:78), HIV-positive women find it especially difficult to disclose their status to their parents, as they fear the consequences. One of the participants in the current study stated: "Hulle families skryf hulle af". ("Their families write them off.") The following quote links the fear of rejection to both the family and the partner: "They are afraid of having that disease and tell their partner or their parents because sometimes they will be rejected by their partners".

They believe that their relationships will suffer as blame and mistrust will arise, as indicated by the following excerpt: “....Scared, because you can't trust everybody, like your partner. Sometimes you don't know what he is doing behind your back. HIV brings mistrust between people". One of the participants told the interviewer of her own anguish before she had the test: "Now me, I was scared, what if I am positive and my boyfriend is negative, where did I get it? Or my boyfriend is positive and I am negative, what will happen to us?"

This is similar to the findings of studies done by Maman et al. (2001:599), Rutenberg, Siwale, Kankasa, Nduati, Ngacha, Oyieke, Geibel and Kalibala (2003:7) and Toivo 
(2005:37). These studies found that the fear was usually not substantiated, as most of the participants had indicated that their partners were supportive and only $5 \%$ of relationships had ended after disclosure.

None of the participants mentioned the possibility of physical danger that could face the woman if her partner becomes aware of her HIV-positive status. However, violence is mentioned in the literature (Bodkin, 2004:230; Maman et al., 2001:600; Rutenberg et al., 2003:7; Stein \& Samet, 1999:266; Temmerman, Ndinya-Achola, Ambani \& Piot, 1995:969).

The second point relating to fear of changes to a pregnant woman's social life is the fear of stigmatisation. This was an underlying theme in most of the interviews. It seems as if the existence of stigma against HIV-positive individuals is accepted as a fact of life and can be considered an underlying reason why pregnant women decide against having an HIV test. Quotes that indicate the fear of stigmatisation were as follows: "What will people say if she is HIV?" "Ander mense gaan sê, sy loop daar by die kliniek, sy het HIV. Daai ding gaan sit by my hart, want ander een gaan vir my sê as ek maer word, hulle gaan sê ek het AIDS". ("Other people are going to say, she's going to the clinic, she has HIV. That lies heavy on my heart, because someone else will say, if I get thin, they're going to say I've got AIDS.")

Some women were even afraid that consenting to be tested could be perceived as an indication that they may be HIV positive and result in their being stigmatised. Aynalem et al. (2004:29) also found that women were afraid that they would be stigmatised by merely accepting HIV testing. They believed that others might see it as an indication that they had engaged in highrisk behaviour.

\section{Organisational factors that influence the decision by pregnant women to be tested for HIV}

Different organisational factors were found to influence the decision by pregnant women to be tested for HIV.

\section{Format of counselling and testing}

The responses of the participants seem to suggest that pregnant women prefer to receive health education in a group, as they receive support from the rest of the group:
"As jy alleen gaan vir die counselling, jy voel nie so, jy kry support maar nie so ..., maar as jy in 'n groep is is lekker so". ("If you go alone for the counselling, you don't feel so, you do get support but not so ....., but if you are in a group..., that's nice.") Cartoux et al. (1999:200) found that pretest counselling presented to a group was just as acceptable and effective as individual counselling, and at the same time more effective in terms of cost and time.

Participants did, however, appreciate the privacy when declaring their intention to be tested or not to the counsellor. It also allowed them to ask personal questions and they needed privacy when they received the test results: "In the group they give the counselling, and if you tell them if you want to test and they do the test, you are alone with the counsellor. I think it is good". "Alleen is beter. Hulle sê vir jou alleen, jy het HIV. Jy kan sommer net soos die ander sit. Die ander mense weet nie". ("Alone is better. They tell you on your own, you have HIV. You can sit just like the others. The other people don't know.")

Some participants expressed the need to be treated as individuals: "You see, we are not the same, we don't have the same heart, the same feelings ... they treat us the same, but we are not the same".

Lack of trust that the clinic staff would honour confidentially can cause pregnant women to decide not to be tested for HIV. This was evident from the following: "We are afraid to go to the hospital because my neighbour is working there; he is working with the test results. I can't go to the hospital". "Hulle sê dit is confidential, dit bly tussen julle. Maar mens is ook maar net mens. Nou werk ek en jy saam. Ek doen die AIDS kursus en dan sê ek, weet jy daai enetjie het ook AIDS". ("They say it's confidential, it stays between you. But a person remains human. Now you and I work together. I do the AIDS course and then I say, you know, that one also has AIDS.") "Maybe the nurse find out that you are positive and she doesn't tell you. She tells the other nurses and they communicate, but they are afraid to tell you, you are positive... That's what they do here at the clinic". A lack of trust and fear of breach of confidentiality by the health personnel is a common theme in the literature (Fylkesnes, 2000:S43; Pool et al., 2001:610; Toivo, 2005:40; Van Dyk \& Van Dyk, 2003:122). Maman et al. (2001:601) also mention that 
individuals who are aware of a possible breach in confidentiality may choose not to be tested for HIV.

One of the participants mentioned that she preferred to be counselled and tested by someone from another community not known to her. She was very uncomfortable with the possibility that she may meet someone on the street who knew her HIV status. This indicates an intense fear of stigmatisation: "I want to be tested by a white person, because they don't know me". "They must get someone from $X X X X X$ who doesn't know me, or someone from $Z Z Z Z Z Z$, a person that doesn't know us, or a white person". Fylkesnes (2000:S43) pointed out that participants in Lusaka were more willing to be tested in a location of their choice than at their local clinic. He attributed this to the high value people place on privacy and the perception that personnel at health facilities are not trustworthy.

One of the participants preferred not to be confronted by the knowledge of her positive HIV status, but would not want to miss the opportunity to benefit from the treatment available. This preference to live in ignorance may be related to the perceived quick deterioration of an HIV-positive person after having received the diagnosis: "Hulle moet nie die mense vra nie, moet net die bloed vat, en skryf by jou papier dat jy nie verstaan nie, maar hulle gee jou die ARV's". ("They mustn't ask the people, just take the blood and write on your paper in a way that you cannot understand, but then give you ARVs.") Bassett (2002:350) and Temmerman et al. (1995:970) recommend a similar option where everybody is tested but where women can 'opt out' from receiving the results and still receive treatment if this is indicated by the results.

\section{Counselling as a source of support}

Another aspect related to organisational factors influencing the decision by pregnant women to be tested for HIV is the amount of support they receive from the counsellors. Participants indicated that they appreciated the counsellors' efforts to reduce their anxiety: "She wanted to make me comfortable." "You see, it was very good, because if you are afraid, you calm down". The participants in the study by Moosa (1998:66) also noted the counselling that they received to be satisfying and cited that it met their needs.

No participant in the current study mentioned the need for posttest counselling. A possible reason may be the focus of the questions on counselling for HIV testing (pretest counselling). Van Dyk and Van Dyk (2003:119) point out that knowing one's HIV status without followup support services or treatment can be detrimental to a person's mental and physical wellbeing and could lead to feelings of fatalism and depression. The importance of ongoing counselling and support was also noted by Doherty, Besser, Donohue, Kamoga, Stoops, Williamson and Visser (2003:17) after they had evaluated the pilot project of the mother-to-child transmission of HIV initiative in South Africa.

\section{Counselling as a source of information}

Participants who consented to be tested because it would benefit the baby made the decision on the basis of knowledge about the measures that can be taken to prevent mother-to-child transmission. They obtained this information from the clinic as well as from other sources: "Hulle sê vir jou alles wat jy moet weet. Hulle gee vir jou pamflette. Dit kom oor die nuus, reg oor die wêreld, word vir jou gesê hoekom die toetse belangrik is". "They tell you everything you must know. They give you pamphlets. It's on the news, all across the world, you're told why the tests are important.") "Die ding wat gemaak het dat ek gaan vir die toets is omdat ek radio luister en na die televisie kyk". ("What made me go for the test is because I listen to the radio and watch television.")

However, participants appreciated the health education they received. The following quote indicates the trouble taken by counsellors to ensure that the patient understands the information: "Sy was baie gaaf en sy het vir my al die inligting gegee wat ek moet weet. Van die dinge het sy vir my vier keer oor gesê sodat ek kon verstaan". ("She was very kind and she gave me all the information that I must know. She told me some of the things four times to ensure that I could understand.") The participants in the study reported by Rutenberg et al. (2003:4) also valued the information they received through counselling as they felt empowered and less helpless.

A number of the participants recommended the availability of more health education material: " $E k$ dink meer plakkate, dat mense weet counselling is belangrik". ("I think more posters, that people know counselling is important.") "Dit sal lekker wees as hulle 
iets kry ... miskien 'n papier om te lees. Hoe dit sal wees, hoe moet hulle maak...". ("It would be nice if they could get something ... Maybe a paper to read. How it will be, what they should do...")

They also recommended that the broader public receive education on the benefits of HIV testing during pregnancy: "Miskien as die mense in die community, as hulle meer inligting kry, hulle sal makliker... dit sal makliker wees vir hulle om te kom toets". ("Maybe if the people in the community, if they get more information, they would .... it would be easier for them to come for testing.")

Pregnant women who participated in the study by Toivo (2005:49) also felt that community education was needed and that both women and men needed to be educated. They hoped that the training would educate women about the importance of VCT to clarify the myths and misconceptions surrounding voluntary antenatal counselling and testing. They also felt that if men were educated, they would encourage their pregnant partners to be tested.

\section{Logistical factors}

Some participants complained about the long periods that they had to wait before consultations at the antenatal clinics: "You come at seven o'clock this morning and it's already after eleven and you're hungry. You are sitting in a queue". This was also found in a study done by Rutenberg et al. (2003:3) in East Africa.

Participants had a solution to this problem. They recommended that services be organised to ensure that patients do not have to wait for long periods: "If they say we must come for counselling, just counselling that day then tomorrow we must come again to see the doctor to see if all is well". "Laat hulle party dae net vir toetse gebruik. Dan weet jy mos. Ek gaan in en ek gaan uit en dit is verby". ("Let them use certain days just for tests. Then you know. I go in and I go out and it's finished.") In contrast to these recommendations, Rutenberg et al. (2003:3) found that women did not like returning on a separate day for counselling, but preferred the service to be integrated.

Participants complained that some of the clinic staff were rude to patients and also lazy: "Van die personeel is baie onbeskof, jy kan nie met hulle werk nie. Jy wag die heeldag en dan skel hulle nog". ("Some of the staff are very rude, you can't work with them. You wait the whole day and then they still scold you.") "They are too lazy! If you come, they say: I am going for coffee and they are gone for too long". Unfortunately this perception of clinic staff is not uncommon. Abrahams, Jewkes and Mvo (2001:245), Birdsall, Nkosi, Hajiyiannis and Parker (2004:8), Bodkin (2004:233) and Pretorius and Greeff (2004:76) also found that pregnant patients perceive the staff of antenatal clinics to be uncaring.

One of the reasons why health workers are perceived to be rude may be frustration caused by work overload. Couper (2004:2) explains how health workers become increasingly callous when they continuously struggle to deliver services to an increasing number of ill people with inadequate resources. A common explanation for staff acting rudely is overwork caused by staff shortages, which leads to low morale. According to Bassett (2002:347), enough counsellors is a prerequisite for an effective VCT service. Some of the participants in the present study recommended that more staff be appointed: "Hulle moet meer mense aanstel, want die personeel is min en van die personeel doen twee werke wat hulle ophou met die hele kliniek en dan word dit vol wat die mense dan ophou". ("They must appoint more people because the staff are few and some of the staff do two jobs that detain them with the whole clinic and then it gets full which detains the people.") Rutenberg et al. (2003:3) found that appointing more staff and reorganising staff's working hours were successful strategies for improving the uptake of HIV counselling services.

\section{CONCLUSIONS}

From the findings it became clear that a variety of factors can influence pregnant women in their decision to be tested for HIV or not. Pregnant women who consent to testing do so because of the perceived benefits to the baby or to themselves if their HIV status is known. Pregnant women need to be ready to be confronted with a possible positive HIV result. Some pregnant women are influenced by family members and friends in their decision to be tested but, in contrast to other studies, no one mentioned that a husband or partner needs to be consulted before the decision is made.

Fear of the life changes that a positive result may cause 
was the main reason given by participants for women deciding not to be tested for HIV. Fears for life changes on a personal level included fear that they may lose their secure livelihood, get ill more quickly and that death may follow soon. The resulting despair that follows may lead to suicide. Fears of social changes included fear of being rejected by their partners owing to mistrust and fear of possible stigmatisation in the community.

Organisational factors can also influence the decision by pregnant women to be tested for HIV. Participants preferred to receive the health education part of the pretest counselling in a group, but appreciated privacy when disclosing their decision regarding testing. They were suspicious of the health personnel not honouring confidentiality of their HIV status. Support during counselling was appreciated and pregnant women wanted to be cared for as individuals.

Participants valued the information they received at the clinic but received information about HIV and prevention of mother-to-child transmission from other sources as well. They recommended that more health education material be used and that the community also receive more information about the importance of HIV testing especially during pregnancy. Participants complained about waiting in long queues and suggested that certain days be designated for HIV testing to accelerate the process. Some pregnant women experienced health personnel as rude to patients and recommended that more staff be appointed.

\section{LIMITATION}

Interviews were conducted in English or Afrikaans and although none of the participants made use of the interpreter available, some participants might have found it difficult to express themselves in these two languages.

\section{RECOMMENDATIONS}

This study formed part of a larger study and the findings were used together with the other results obtained to formulate BPGs for counselling for HIV testing during pregnancy. On the basis of the findings of this part of the study, the following recommendations can be made:

Recommendations for nursing practice
- Health personnel must assess pregnant women for readiness for HIV testing. If they do not want to test immediately after counselling, they must be given an opportunity to reflect on it and get other opportunities to be tested.

- Employees of clinics must continually be reminded of the importance of keeping client information confidential. The public must be encouraged to report incidences where confidentiality was not protected and justice must be seen to be done.

- Suitable health educational material must be used and if available material is not suitable, new material must be developed.

- Community campaigns and projects must be used to educate the community regarding the importance of HIV testing, especially during pregnancy.

- Opportunities should be arranged where staff can participate in value clarification activities to promote a caring attitude.

- Nursing management should use all means possible to ensure that enough health personnel are appointed and should consult patients regarding the scheduling of services.

\section{Nursing education}

Health professionals must be trained to provide individualised care.

\section{Nursing research}

Studies need to be conducted to investigate the effectiveness of interventions to reduce stigma and improve staff attitude. There is a longstanding need for research to determine staffing norms for nursing staff as well as counsellors in relation to different tasks and client loads experienced.

\section{SOURCES OF SUPPORT}

North-West University

National Research Foundation: Thuthuka Researcherin-training grant

\section{REFERENCES}

ABRAHAMS, N; JEWKES, R \& MVO, Z 2001: Health care-seeking practices of pregnant women and the role of the midwife in Cape Town, South Africa. Journal of Midwifery \& Women's Health, 
46(4):240-247.

AYNALEM, G; MENDOZA, P; FREDERICK, T \& MASCOLA, L 2004: Who and why? HIV-testing refusal during pregnancy: Implications for pediatric HIV epidemic disparity. AIDS and Behavior, 8(1):2531.

BARRON, P; DAY, C \& MONTICELLI, F 2007: The district health barometer - year 2006/07. Durban: Health Systems Trust.

BASSETT, MT 2002: Ensuring a public health impact of programs to reduce HIV transmission from mothers to infants: The place of voluntary counseling and testing. American Journal of Public Health, 92:347-351.

BEEVOR, AS \& CATALAN, J 1993: Women's experience of HIV testing: The views of HIV positive and negative women. AIDS Care, 5(2):177-186.

BIRDSALL, K; NKOSI, Z; HAJIYIANNIS, H \& PARKER, W 2004: Prevention of mother-to-child transmission (PMTCT) in South Africa: Analysis of calls to the National AIDS Helpline. http:// www.cadre.org.za/pdf/pdf/CANPMTCT.pdf (Accessed on 4 April 2008).

BODKIN, C 2004: Best practice guidelines for midwives' antenatal assessment and management of HIV positive pregnant women. Johannesburg: University of the Witwatersrand (Unpublished DPhil thesis).

BOYD, FM; SIMPSON, WM; HART, GJ; JOHNSTONE, FD \& GOLDBERG, DJ 1999: What do pregnant women think about the HIV test? A qualitative study. AIDS Care, 11(1):21-29.

BURNS, N \& GROVE, SK 2005: The practice of nursing research: Conduct, critique and utilization; $5^{\text {th }}$ edition. St Louis: Elsevier.

CARTOUX, M; MSELLATI, P; MEDA, N; WELFFENS-EKRA, C; MANDELBROT, L; LEROY, V; VAN DE PERRE, P \& DABIS, F 1998: Attitude of pregnant women towards HIV testing in Abidjan, Côte d'Ivoire and Bobo-Dioulasso, Burkina Faso. AIDS, 12:2337-2344. CARTOUX, M; SOMBIE, I; VAN DE PERRE, P; MEDA, N; TIENDREBEOGO, S \& DABIS, F 1999: Evaluation of 2 techniques of HIV pre-test counseling for pregnant women in West Africa. Ditrame Study Group. International Journal of STD \& AIDS, 10(3):199-201.

COUPER, ID 2004: Reframing the HIVIAIDS debate in developing countries 1: Setting the scene. Rural and Remote Health 4, 280. http://www.rrh.org.au/publishedarticles/article print 280.pdf (Accessed on 11 May 2007).

CRESWELL, JW 2003: Research design: Qualitative, quantitative and mixed method approaches. Thousand Oaks: Sage.

DE PAOLI, MM; MANONGI, R \& KLEPP, K-I 2002: Counsellors' perspectives on antenatal HIV testing and infant feeding dilemmas facing women with HIV in northern Tanzania. Reproductive Health Matters, 10(20):144-156.

DE VOS, AS 2005: Qualitative data analysis and interpretation. (In: De Vos, AS; Strydom, H; Fouche, CB \& Delport, CSL eds.
2005: Research at grass roots. Pretoria: Van Schaik, pp 286313).

DOHERTY, T; BESSER, M; DONOHUE, S; KAMOGA, N; STOOPS, N; WILLIAMSON, L \& VISSER, R 2003: An evaluation of the prevention of mother-to-child transmission (PMTCT) of HIV initiative in South Africa: Lessons and key recommendations. Durban: Health Systems Trust.

FERNANDEZ, MI; WILSON, TE; ETHIER, KA; WALTER, EB; GAY, CL \& MOORE, J 2000: Acceptance of HIV testing during prenatal care. Public Health Reports, 115(5):460-468.

FYLKESNES, K 2000: Consent for HIV counseling and testing. Lancet Perspectives, 356:S43.

GAILLARD, P; MEILIS, R; MWANYUMBA, F; CLAEYS, P; MUIGAI, E; MANDALIYA, K; BWAYO, J \& TEMMERMAN, M 2000: Consequences of announcing HIV seropositivity to women in an African setting: Lessons for the implementation of HIV testing and interventions to reduce mother-to-child HIV transmission. (In: International AIDS Society. Abstract book. Volume 1: Paper read at $13^{\text {th }}$ International AIDS Conference held in Durban on 9-14 July 2000, p 334).

GILLHAM, B 2000: The research interview. London: Continuum. GRANEHEIM, UH \& LUNDMAN, B 2004: Qualitative content analysis in nursing research:Concepts, procedures and measures to achieve trustworthiness. Nurse Education Today, 24(2):105112.

GREEFF, M 2005: Information collection: Interviewing. (In: De Vos, AS; Strydom, H; Fouche, CB \& Delport, CSL eds. 2005: Research at grass roots. Pretoria: Van Schaik, pp 286-313).

KREFTING, L 1991: Rigor in qualitative research: The assessment of trustworthiness. American Journal of Occupational Therapy, 45(3):214-222.

KVALE, S 1996: Interviews: An introduction to qualitative research interviewing. Thousand Oaks: Sage.

MABUNDA, G 2006: Voluntary HIV counseling and testing: Knowledge and practices in a rural South African village. Journal of Transcultural Nursing, 17(1):23-29.

MAMAN, S 2003: To disclose or not to disclose: An overview of women's HIV serostatus disclosure experiences globally. (In: USAIDS/SYNERGY. Women's experiences with HIV serodisclosure in Africa: Implications for VCT and PMTCT. Washington: USAIDS, pp 7-11).

MAMAN, S; MBWAMBO, J; HOGAN, NM; KILONZO, GP \& SWEAT, M 2001: Women's barriers to HIV-1 testing and disclosure: Challenges for HIV-1 voluntary counseling and testing. AIDS Care, 13(5):595-603.

MARCENKO, MO \& SAMOST, L 1999: Living with HIVIAIDS: The voices of HIV positive mothers. Social Work, 44(1):36-45. MCCOY, D; BESSER, M; VISSER, R \& DOHERTY, T 2002: Interim findings on the National PMTCT pilot sites: Lessons and 
recommendations. Durban: Health Systems Trust.

MCINTYRE, J 2005: Prevention of mother-to-child transmission of HIV: Treatment options. Expert Review of Anti-infective Therapy, 3(6):971-980.

MINNIE, CS 2007: Best practice guidelines for HIV testing during pregnancy. Potchefstroom: North-West University (Unpublished $\mathrm{PhD}$ thesis).

MINNIE, CS \& GREEFF, M 2006: The choice of baby feeding mode within the reality of the HIVIAIDS epidemic: Health education implications. Curationis, 29(4):19-27.

MOOSA, EZ 1998: A survey of the pregnant HIV positive women's perception of the counseling they receive at clinics of two hospitals in Durban. Durban: University of Natal (Unpublished MCur thesis). NATIONAL DEPARTMENT OF HEALTH See South Africa.

OKUN, BF 2002: Effective helping: Interviewing and counseling technique; $6^{\text {th }}$ edition. Louisville: Brooks/Cole.

PARRA, EO; DORAN, TI; IVY, LM; ARANDA, JM \& HERNANDEZ, C 2001: Concerns of pregnant women about being tested for HIV: A study in a predominately Mexican-American population. AIDS Patient Care and STDs, 15(2):83-93.

POLIT, DF \& BECK, CT 2004: Nursing research: Principles and methods; $7^{\text {th }}$ edition. Philadelphia: Lippincott, Williams \& Wilkins. POOL, R; NYANZI, S \& WHITWORTH, AG 2001: Attitudes to voluntary counseling and testing for HIV among pregnant women in rural South-West Uganda. AIDS Care, 13(5):605-615.

PRETORIUS, CF \& GREEFF, M 2004: Health-service utilization by pregnant women in the greater Mafikeng-Mmabatho district. Curationis, 27(1):72-81.

RICHARDS, L 2005: Handling qualitative data. London: Sage. ROMERO-GUTIERREZ, G; DELGADO-MARCIAS, AA; MORAESCOBAR, Y; PONCE-PONCE DE LEON, AL \&AMADOR, N 2007: Mexican women's reasons for accepting or declining HIV antibody testing in pregnancy. Midwifery, 23(1):23-27.

RUTENBERG, N; SIWALE, M; KANKASA, C; NDUATI, R; NGACHA, DM; OYIEKE, J; GEIBEL, S \& KALIBALA, S 2003: HIV voluntary counseling and testing: An essential component in preventing mother-to-child transmission of HIV. Horizons Research summary. Population Council: Washington, DC. http:// www.uniteforchildren.org/knowmore/files/Horizons pmtctvct.pdf (Accessed on 4 April 2008).

SANNE, I \& SMEGO, R 1998: HIV vertical transmission - The immobility of indecision! Southern African Journal of Epidemiology and Infection, 13(2):38-39.

SOLOMON, V; VAN ROOYEN, H; GRIESEL, R; GRAY, D; STEIN, J \& NOTT, V 2004: Critical review and analysis of voluntary counselling and testing literature in Africa. Durban: Health Systems Trust. SOON, CW \& BARNARD, A 2002: A phenomenographic approach to examine the different ways HIV patients understand the experience of counselling. Journal of Mental Health, 1(2):14-
23.

SOUTH AFRICA, NATIONAL DEPARTMENT OF HEALTH 2007: Report: National HIV and syphilis prevalence survey in South Africa 2006. http://www.doh.gov.za/ aids/index.html (Accessed on 31 August 2007).

STEIN, MD \& SAMET, JH 1999: Disclosure of HIV status. AIDS Patient Care, 13(5):265-267.

TEMMERMAN, M; NDINYA-ACHOLA, J; AMBANI, J \& PIOT, P 1995: The right not to know HIV-test results. Lancet, 345:969-970.

TOIVO, A 2005: Perceptions and experiences of pregnant women towards HIV voluntary antenatal counselling and testing in Oshakati Hospital, Namibia. Cape Town: University of the Western Cape (Mini MSc thesis).

UNICEF/UNAIDS/WHO/UNFPA 2000: African regional meeting on pilot projects for the prevention of mother-to-child transmission of HIV. Report of meeting held on 27-31 March in Gaborone, Botswana. http://www. popline.org/docs/1515/275414.html (Accessed on 4 April 2008).

VAN DYK, AC \& VAN DYK, PJ 2003: "What is the point of knowing?" Psychosocial barriers to HIVIAIDS voluntary counseling and testing programmes in South Africa. South African Journal of Psychology, 33(2):118-125.

WHO See World Health Organization.

WOODS, NF \& CATANZARO, M 1988: Nursing research: Theory and practice. St Louis: Mosby.

WORLD HEALTH ORGANIZATION 2007: Mother-to-child transmission of HIV. http://www.who.int/hiv/mtct/en/index.html (Accessed on 20 April 2007).

YOSHIOKA, MR \& SCHUSTACK, A 2001: Disclosure of HIV status: Cultural issues of Asian patients. AIDS Patient Care and STDs, 15(2):77-82. 